\title{
INFLUENCE OF Ag NANOPARTICLES INCORPORATED INTO SILICA FILM ON ION YIELD IN UV LASER DESORPTION/IONIZATION MASS SPECTROMETRY
}

\author{
Fesenko T.V. *, Snegir S.V., Surovtseva N.I., Smirnova N.P., Pokrovskiy V.A. \\ Chuiko Institute of Surface Chemistry of National Academy of Sciences of Ukraine \\ 17 General Naumov Str., Kyiv, 03164, Ukraine
}

The efficiency of UV laser desorption/ionization from the surface of mesoporous silica films containing Ag nanoparticles of various sizes has been examined using methylene blue as a probe molecule. It has been shown that a rise in both AgNPs concentration and their size to 5-12 $\mathrm{nm}$ intensifies the nanoparticles stimulating effect on methylene blue desorption/ionization. The increase in Ag concentration in the silica host matrix from 3 to $10 \%$ raises fivefold the methylene blue cation peak intensity. The ion yield increase observed is discussed based on the phenomenon of local heating and local surface plasmon resonance under UV laser irradiation.

Keywords: laser desorption/ionization, mesoporous silica film, silver nanoparticles, methylene blue, plasmon resonance

\section{INTRODUCTION}

Nanocomposites applicable in different novel technologies are actively explored with a view to upgrade mass-spectrometric experiments [1]. As applied to analysis of organic substances with low molecular masses matrix-free procedures that use specific properties of nanostructured surfaces, noble metal nanoparticles (NPs) have attracted a lot of attention and become a growing field [2]. Surface-assisted laser desorption/ionization (SALDI) substrates are used for mass-spectrometric analysis of various molecules with high reproducibility. For example, for Au-coated nanospiked polyurethane substrates replicated by a nanolithography method from silicon nanospike structures formed with femtosecond laser irradiations, the effective ionization was the result of the surface plasmon excitation [3].

A possibility has been demonstrated of using gold nanoparticles of 2-10 $\mathrm{nm}$ in diameter for the phosphopeptides determination [4]. Nanoparticles of $\mathrm{Ag}, \mathrm{Au}, \mathrm{Pt}, \mathrm{Cu}$ without additional modification facilitate the ionization of peptides and synthetic polymers [5]. Silver nanoparticles (AgNPs) are used for mass-spectrometric identification of estrogens [6], peptides [7], cysteine, and homocysteine in human urine [8]. Acting as accumulators/transmitters of UV laser light, AgNPs with the size of $10-160 \mathrm{~nm}$ were found to

* corresponding author t.fesenko@gmail.com assist desorption/ionization of biomolecules with little or no induced fragmentation [5-8]. However, in respect to mass-spectrometry, the AgNPs with the sizes less than $10 \mathrm{~nm}$ have not yet been investigated in detail.

Previous mass spectrometric studies of $\mathrm{Au}$ and AgNPs revealed the ion yield efficiency to be dependent on the excitation wavelength as well as on NPs size, shape, agglomeration, and the surface density of NPs [9-10]. At the laser wavelengths out of local surface plasmon resonance (LSPR) absorption band, especially at those longer then the peak of plasmon absorption, the capability to generate a detectable ion signal decreased rapidly [9].

The aim of this study is elucidation of the influence of the particles size and their concentration in films on the mass-spectrometric data.

Composite materials containing AgNPs of different sizes and concentrations embedded into $\mathrm{SiO}_{2}$ host matrix $\left(\mathrm{Ag} / \mathrm{SiO}_{2}\right)$ were the object of this research. Thin mesoporous silica films were taken as a chemically passive material to prevent active $\mathrm{Ag}$ oxidation [11]. The use of a matrix allows for achieving a uniform distribution of both silver species and the substance tested over the substrate surfaces.

\section{MATERIALS AND METHODS}

A template sol-gel method was applied for preparing thin optically transparent mesoporous 
silica films doped with $\mathrm{Ag}$ deposited onto glass slides. Tetraethoxysilane (TEOS) was mixed with a water-ethanol solution for pre-hydrolysis. $1 \mathrm{M} \mathrm{HNO}_{3}$ solution was used to adjust the $\mathrm{pH}$ value on hydrolysis of TEOS. An ethanol solution of a template agent (a nonionic triblockcopolymer of propyleneoxide with ethyleneoxide $\mathrm{EO}_{20} \mathrm{PO}_{70} \mathrm{EO}_{20}$, Pluronic P123) used to create ordered mesopores in the films was added to the solution of alkoxide after pre-hydrolysis for 4-16 h. To form Ag nanoparticles embedded within the oxide films, an appropriate amount of $\mathrm{AgNO}_{3}$ was added to precursor sols. The concentration of $\mathrm{Ag}^{+}$ions was varied from 3 to 10 at. $\%$ in resulted films. For film deposition onto glass substrates, a dip-coating technique was utilized. After deposition, gelation, and gel ripening, the films were dried in air at room temperature for $2 \mathrm{~h}$. Then the dried films were sintered in a furnace at the heating rate $\beta=2{ }^{\circ} \mathrm{C} / \mathrm{min}$ to $250{ }^{\circ} \mathrm{C}$, and at $\beta=0.25^{\circ} \mathrm{C} / \mathrm{min}$ from 250 to $350^{\circ} \mathrm{C}$. After that the temperature was elevated to 400 or $450{ }^{\circ} \mathrm{C}$ at $\beta=3{ }^{\circ} \mathrm{C} / \mathrm{min}$ and the systems were kept at a certain temperature for $2 \mathrm{~h}$. P123 burns out at these temperatures, hence this process should be carefully controlled for keeping the ordered porous structure of the oxide film $/ \mathrm{Ag}$ nanoparticles.

The films synthesized are stable. This is confirmed by the reproducibility of electronic spectra. LSPR position and intensity do not change considerably during 1 year.

Visualization of the substrate surfaces was performed on a SEM Zeiss Supra 40 field emission apparatus. To prevent charge accumulation, the films were covered with a thin layer of carbon. Optical spectra (transmission mode) of the films were recorded using a Lambda UV-Vis (Perkin Elmer) spectrometer.

To evaluate the activity of AgNPs as substrates for LDI, the methylene blue (MB) molecules were adsorbed on the surface of films from aqueous solution. The optical density in the maximum of an methylene blue (MB) absorption peak was adjusted to 0.4 for all the samples what corresponds to the dye concentration of $0.9 \pm 0.05 \cdot 10^{-4} \mathrm{~mol} / \mathrm{g}$. The intensity of a MB cation peak $(\mathrm{m} / \mathrm{z} 284)$ was the basic criterion of the tested nanocomposites efficiency.

Laser desorption/ionization time-of-flight mass spectrometry was carried out in a positive-ion extraction mode on a Bruker Daltonics Autoflex II instrument ( $3 \mathrm{~ns}$ pulse with $20 \mathrm{~Hz}$ frequency; laser fluence $60 \mathrm{mj} / \mathrm{cm}^{2}$; accelerating voltage $20 \mathrm{keV}$; nitrogen UV-laser at $337 \mathrm{~nm}$ wavelength; linear detection mode, delayed extraction $10 \mathrm{~ns}$ ). A selfmade sample holder for glass substrates was developed. Data averaging was provided by means of spectra summation on the different spots of the substrate surface under fixed instrument parameters for the acquisition of the resulting mass-spectra.

\section{RESULTS AND DISCUSSION}

Surface morphology of $\mathrm{Ag} / \mathrm{SiO}_{2}$ films. According to our previous study [11], the silica film structure is slightly ordered, keeping certain areas of the hexagonal mesostructure with the mean pore size of $\sim 10 \mathrm{~nm}$ and $\mathrm{S}_{\mathrm{BET}}=650 \mathrm{~m}^{2} / \mathrm{g}$. The conditions of heat processing allow for controlling such film characteristics as the purity, stability, porosity, and size of AgNPs. The temperature range and duration of annealing have been selected to ensure the removal of pore-forming organic material, the creation of mesoporous $\mathrm{SiO}_{2}$ framework, and the thermoreduction of Ag.

The pore structure of films influences the formation of silver nanoparticles with a uniform size distribution. At the heating stage, Ag clusters and particles change their morphology and location in the film (in pores or at the outer surface of the film depending on the size of particles and pores, mass transfer processes, etc.). Composites with silver nanoparticles/porous oxide films demonstrate certain changes in the pore structure in comparison with those of individual oxide films. In the case of silica, silver doping leads to the formation of secondary porosity with much larger pores. SEM images show a relatively uniform distribution of silver nanoparticles deposited predominantly at the outer surface and entrapped into subsurface layer in the thin silica films.

Fig. 1 shows the $\mathrm{SEM}$ images of $\mathrm{Ag} / \mathrm{SiO}_{2}$ films after heat treating at 400 and $450{ }^{\circ} \mathrm{C}$ with the corresponding histograms demonstrating the size distribution of $\mathrm{Ag}$ nanoparticles. These silver nanoparticles have the spherical shape with different diameters of the particles estimated for different samples: $d \leq 4 \mathrm{~nm}$ for $\mathrm{Ag} / \mathrm{SiO}_{2}\left(400{ }^{\circ} \mathrm{C}\right)$ and $d \approx 5-12 \mathrm{~nm}$ for $\mathrm{Ag} / \mathrm{SiO}_{2}\left(450^{\circ} \mathrm{C}\right)$. Thus, the heat treatment of nanocomposites with $\mathrm{Ag}$ content within $3-10 \%$ at $400{ }^{\circ} \mathrm{C}$ leads to the formation of AgNPs smaller than $4 \mathrm{~nm}$. SEM images are evidence of that (Fig. $1 a, b$ ). Increasing of the calcination temperature to $450{ }^{\circ} \mathrm{C}$ leads to the 
agglomeration of $\mathrm{Ag}$ nanoparticles (Fig. $1 c, d$ ).

The SEM results indicate a large separation

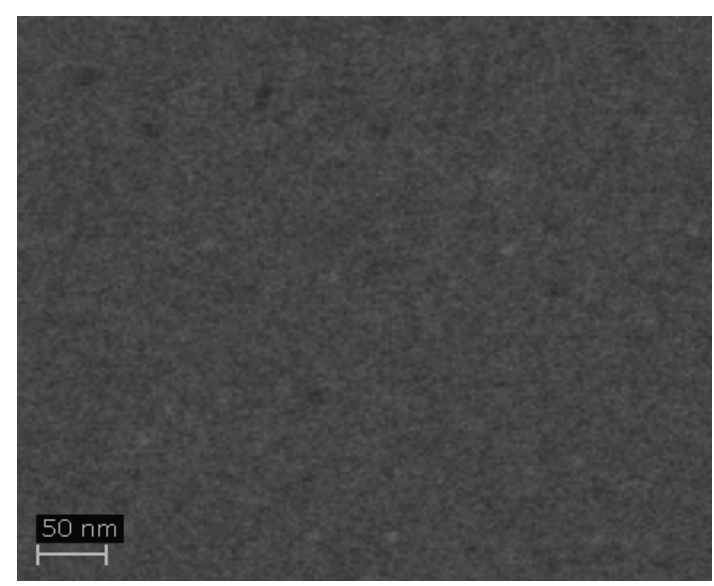

$a$

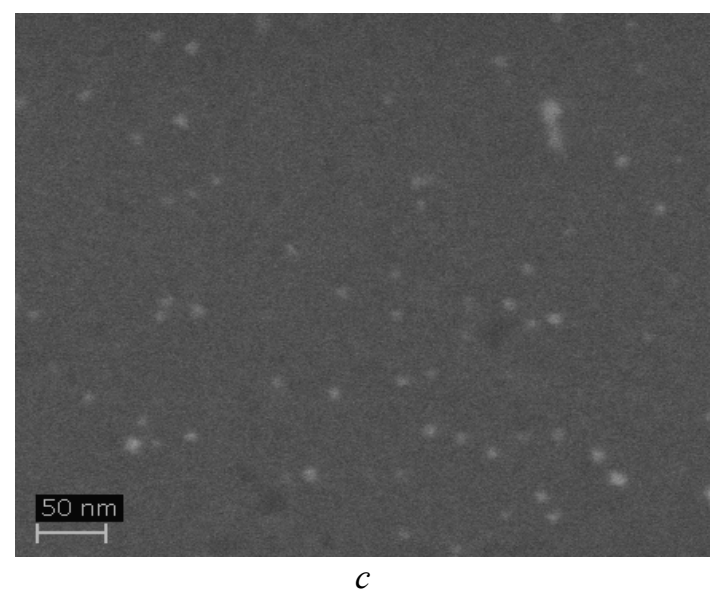

between nanoparticles, so that the electrodynamical coupling does not affect their optical spectra.

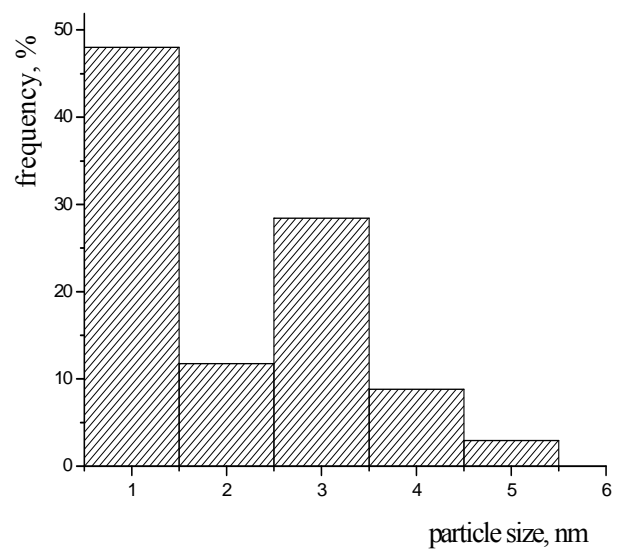

$b$

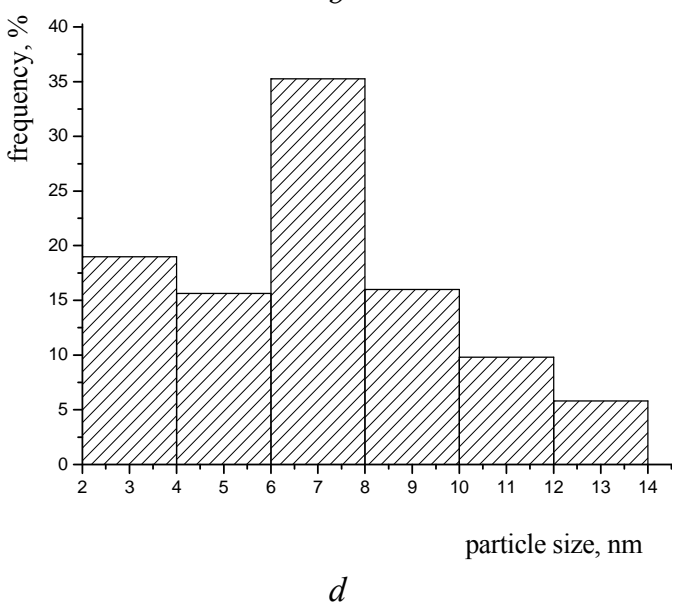

Fig. 1. SEM images with corresponding size distribution histograms of silver nanoparticles in $\mathrm{Ag} / \mathrm{SiO}_{2}$ films treated at $400{ }^{\circ} \mathrm{C}-a, b$ and at $450{ }^{\circ} \mathrm{C}-c, d$

UV-Vis spectroscopy. According to the method described, the different duration and temperature of annealing of mesoporous silica samples cause changes in the size of spherical NPs in the range of 2 to $12 \mathrm{~nm}$ and a relative shift of the optical absorption maximum [12], changes in the resonance peak intensity and in the UV-spectrum curve form.

The absorption spectra (Fig. 2) of the films treated at $400{ }^{\circ} \mathrm{C}$ (dashed curve) show a maximum near $380 \mathrm{~nm}$ that originates from Ag nanoparticles on $\mathrm{SiO}_{2}$ surface [13] and a wide band with a diffuse maximum around $423 \mathrm{~nm}$. The authors $[14,15]$ attribute the latter to the weak LSPR of small-sized (under $4 \mathrm{~nm}$ ) AgNPs. As compared with the LSPR maximum of AgNPs of 5-12 nm size (solid curve), it is effectively red-shifted. Its height decreases dramatically while the spectral width become broader. These effects are related to a wide distribution of particle sizes in the host matrix as well as to a quantum size effect for NPs $\leq 4 \mathrm{~nm}$ [15-17].

Increasing the bulk concentration of $\mathrm{AgNO}_{3}$ in the film precursor from 3 to $10 \%$ makes no influence on the peak position in the electronic spectra of resulting nanocomposites. It means that under the given synthesis technique, at the $\mathrm{Ag}$ concentration within the range mentioned, the AgNPs size changes insignificantly, whereas the number of NPs per surface area unit depends on the concentration.

Elevating the drying temperature up to $450{ }^{\circ} \mathrm{C}$ results in the coalescence of AgNPs. Their growth leads to changes in the UV-spectra. For the samples treated at $450^{\circ} \mathrm{C}$, the absorption spectrum (Fig. 2, solid curve) exhibits an intense broad band at $400 \mathrm{~nm}$ which is the characteristic local surface 
plasmon resonance band (owing to the coherent oscillation of electrons in the conduction band of AgNPs). SEM images reveal that the films obtained contain spherical AgNPs with the diameter of $5 \div 12 \mathrm{~nm}$ (Fig. $1 \mathrm{c}$ ) and the surface density of $(2 \div 2.4) \times 10^{3} \mathrm{NPs} \cdot \mu \mathrm{m}^{-2}$.

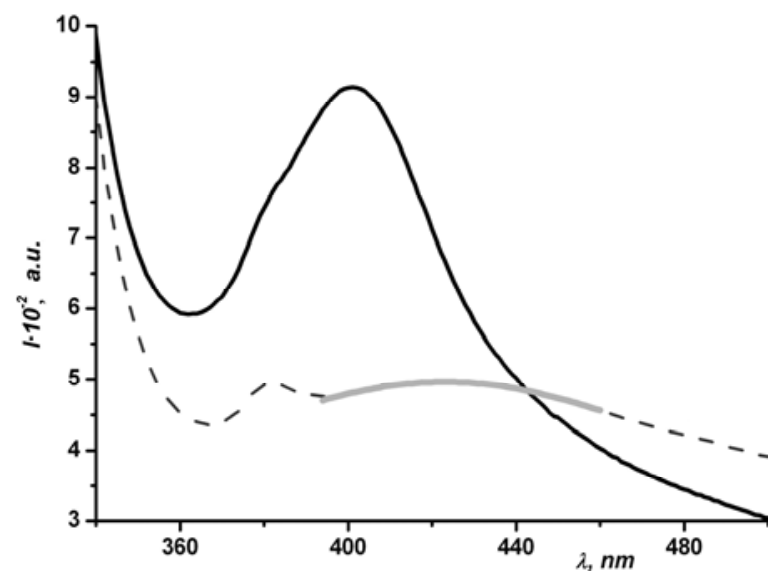

Fig. 2. UV absorption spectra of $\mathrm{SiO}_{2} / \mathrm{Ag}$ films treated at $400{ }^{\circ} \mathrm{C}$ (dash curve) and $450{ }^{\circ} \mathrm{C}$ (solid curve)

LDI-spectrometry. The positive ion massspectra were compared of $\mathrm{MB}$ adsorbed on the

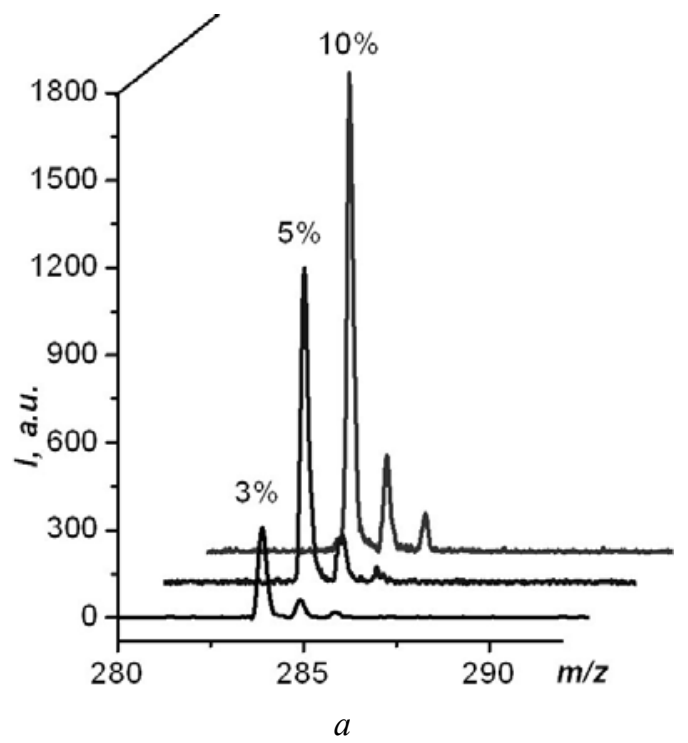

surface of silica films doped with AgNPs of different concentration. To get qualitative massspectra of the dye, these samples required a lower laser power than $\mathrm{MB}$ samples adsorbed on pure $\mathrm{SiO}_{2}$. In the mass-spectra of all investigated substrates, the main peaks were in the area of the dye cation $\mathrm{M}^{+}$with the molecular weight of $284 \mathrm{Da}$. It has been demonstrated that there is a correlation between the ion yield of MB cations adsorbed on the surface of the silica matrix containing AgNPs and the dimensions of NPs. The measurements showed a variation of the MB cation peak intensity with the variation of the silver concentration in nanocomposite. It is clearly seen that an increase in the $\mathrm{Ag}$ ions concentration from 3 to $10 \%$ in the films treated at $400{ }^{\circ} \mathrm{C}$ causes the fivefold raising of the $\mathrm{MB}$ cation desorption peak intensity on the surface of AgNPs loaded substrates (Fig. $3 a$ ). It points to a stimulating effect of AgNPs in the silica matrix on the process of the desorption/ionization of adsorbed MB cations. When analyzing this fact, it is possible to suppose that a more effective transfer of the laser energy to adsorbed MB cations takes place in this case.

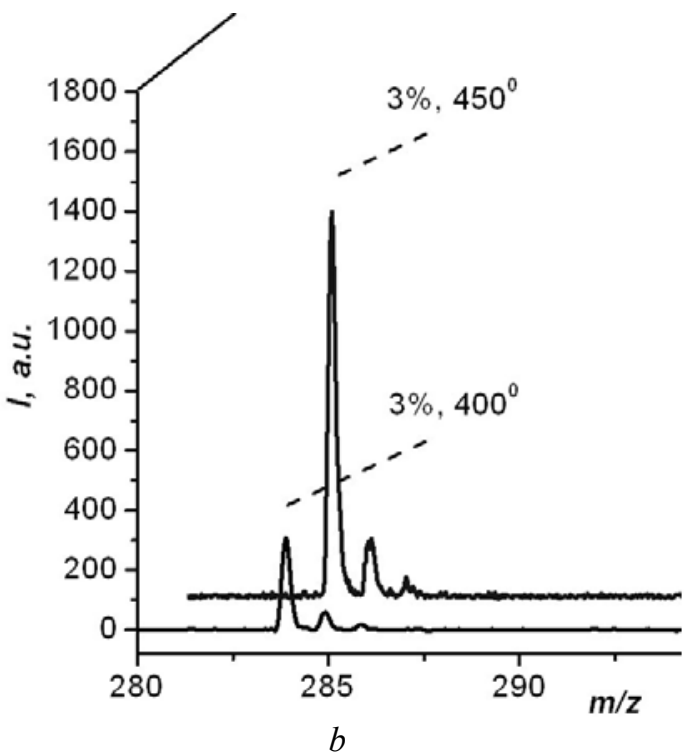

Fig. 3. Fragments of positive ion mass-spectra of methylene blue obtained on the $\mathrm{SiO}_{2} / \mathrm{Ag}$ films prepared at $400{ }^{\circ} \mathrm{C}$ with various amount of $\mathrm{AgNO}_{3}(3,5,10 \%)$ in sol (a) and on the $\mathrm{SiO}_{2} / \mathrm{Ag}$ films obtained at 450 and $400{ }^{\circ} \mathrm{C}$ with $3 \%$ of $\mathrm{Ag}(b)$

When examining the aforementioned observations, we can choose the photoinduced heating of the composite material surface as the main factor having an impact upon desorption/ionization efficiency. Reasoning from the ratio of the coefficient of UV-laser adsorption and the heat conductivity of metal NPs and the silica matrix, we can conclude that just NPs are the more active component in the process of the energy transfer. A portion of the NPs thermal energy (its 
excess originates from the optical excitation) passes to the bulk of the porous matrix so locally elevating the surrounding temperature and, perhaps, weakening the interaction of $\mathrm{MB}$ with the substrate. The degree of NPs aggregation also affects the heat transmission significantly. The temperature increase that appears in the system can be strongly enhanced due to an accumulative effect and Coulomb interaction [18].

As an important parameter influencing ion formation, the total NPs surface area has been denoted [9]. Taking into account these considerations, an intensification of the ion yield of the test compound (Fig. $3 a$ ) is expected at raising concentration of inclusions in the silica matrix. At an even AgNPs distribution on the substrate surface, an additive effect of the $\mathrm{Ag}$ concentration growth up to $10 \%$ is showing up in the gradual increase of the tested substance ion yield.

The key distinction in the electronic spectra of nanocomposites (Fig. 2) annealed at different temperatures emerges in the presence of an uneven enhancement in the absorption of photons with wavelengths characteristic of the LSPR. This phenomenon is observed for the substrates heat treated at $450{ }^{\circ} \mathrm{C}$. At the desorption from the surface of such films, the MB cation peak intensity has been found to be roughly three times higher in comparison with the composites treated at $400{ }^{\circ} \mathrm{C}$ with the same $\mathrm{Ag}$ percentage in the parent sol (Fig. 3 b). So, there is an explicit connection between the ion signal intensity and the effect of LSPR. As a result of heat treatment at T $>400^{\circ} \mathrm{C}$, the coalescence of AgNPs into bigger (5-12 nm) AgNPs is achieved. Absorbing more UV radiation quanta, such particles more strongly stimulate the process of MB desorption and ion formation.

Clarifying the ionic current increase in the case of 5-12 nm AgNPs, apart from the factors of local heating and the drastic specific particle surface growth, we should consider several other parameters that may affect such a result of the experiment.

It is known that the interaction of the pulsed UV light with a silver nanoparticle of the average size of $8 \mathrm{~nm}$ leads to a strong photoluminescence (PL) from silver because of radiative electron interband transitions and the radiative decay of the surface plasmons in silver nanoparticles [19]. The experimental data point to the dependence of the intensity and peak position in PL spectra of $\mathrm{Ag} / \mathrm{SiO}_{2}$ composites on the excitation wavelength and sizes of silver nanoparticles. It has been revealed that the shift of the bands in the PL spectra may be caused by the strong coupling of the emitted photon to LSPR band. Author's [19] "surface plasmon-photon" polariton coupling hypothesis supposes that as a result of such coupling, the states of the emitted photon and surface plasmon can attract each other resulting in the shift of the photon energy value to the LSPR side.

An effective mechanism of energy transfer in the discussed "dye-metallic nanoparticle" system may involve local surface plasmons. Resonant processes cause the maximum enhancement of local electric fields close to the surface of the particles and improve the effectiveness of the transfer of the plasmon excitation energy to dye molecules. It has been found that the contribution of the plasmon mechanism to the total rate of energy transfer dominates (exceeds the rate of transfer by one to two orders of magnitude in the absence of conducting bodies in the system) when the molecules occur close to the metal surface $[20,21]$. Photodesorption is directly dependent on the quenching rate of electronic excitation. It rises substantially at the resonance of optical radiation with plasmon oscillations of metallic NPs due to a light wave field gain on their surface.

Considerations about the samples annealed at $450{ }^{\circ} \mathrm{C}$ do not exclude the role of local heating. The resultant evolved heat depends not only on the number of NP but on the inter-NP distance and NP arrangement. Clustering of metal NPs can significantly affect the total heat generation. Moreover, as follows from previous experiments [18], the heat generation becomes especially strong in the case of metal NPs in the regime of plasmon resonance.

\section{CONCLUSIONS}

LDI experiments with exciting laser wavelength of $337 \mathrm{~nm}$ reveal more effective stimulation of the $\mathrm{MB}$ ion generation on the surface of $\mathrm{Ag} / \mathrm{SiO}_{2}$ composites and the existence of some interesting relationships between substrate features and mass-spectra intensities. Thus, the presence of AgNPs at the surface of the tested substrates promotes efficient energy transfer to adsorbed molecules in LDI. Due to the fact that the interaction of laser radiation with AgNPs leads to a superposition of several processes, such as local heating, LSPR, photoluminescence, and quantitative data on the energy dissipation accompanying these processes 
are unknown, it is incorrect to single out the exceptional role of any of them. However, we are inclined to assume that the local heating and LSPR are dominating processes for substrates containing AgNPs smaller than $4 \mathrm{~nm}$ and for 5$12 \mathrm{~nm}$ AgNPs, respectively.

The targeted usage of mesoporous oxide films as a host material appears to be prospective for the development of methodical approaches to LDI of small molecules. Such substrates seem to be attractive due to the controllable film porosity and morphology modification. The combination of an inert film and a metal component has significant advantages over other matrix-free approaches as it provides a possibility to control the size of incorporated particles and gives an opportunity to reduce the aggregation of metal NPs.

\title{
Вплив наночастинок срібла, інкорпорованих у кремнеземну матрицю, на іонний вихід у мас-спектрометрії з лазерною десорбцією/іонізацісю
}

\author{
Фесенко Т.В., Снегір С.В., Суровцева Н.І., Смірнова Н.П., Покровський В.О.
}

Інститут хімії поверхні ім. О.О. Чуйка Національної академії наук України вул. Генерала Наумова, 17, Київ, 03164, Україна, t.fesenko@gmail.com

Вивчено ефективність лазерної десорбиї/іонізації з поверхні мезопоруватих кремнеземних плівок, що містять наночастинки срібла різного розміру, при використанні метиленового блакитного як тестової речовини. Показано, що як зростання концентрачї̈ срібла, так $i$ збільшення розмірів наночастинок до 5-12 нм посилює стимулюючу дію наночастинок на десорбиію/іонізацію метиленового блакитного. Збільшення концентрації наночастинок у матрииі з 3 до 10\% п'ятикратно збільшує інтенсивність піка катіона барвника. Зростання іонного виходу, ще спостерігається, обговорюється, виходячи з явищ локального розігріву та локалізованого плазмонного резонансу при опроміненні УФ лазером.

\section{Влияние наночастиц серебра, инкорпорированных в кремнеземную матрицу, на ионный выход в масс-спектрометрии с лазерной десорбцией/ионизацией}

\author{
Фесенко Т.В., Снегирь С.В., Суровцева Н.И., Смирнова Н.П., Покровский В.А.
}

Институт химии поверхности им. А.А. Чуйко Национальной академии наук Украинь ул. Генерала Наумова, 17, Киев, 03164, Украина, t.fesenko@gmail.com

Изучена эффективность лазерной десорбиии/ионизачии $c$ поверхности мезопористых кремнеземных пленок, содержащих наночастицы серебра различного размера, при использовании метиленового голубого в качестве тестового вещества. Показано, что как рост кониентрации серебра, так и увеличение размеров наночастии до 5-12 нм усиливает стимулирующее действие наночастии на десорбиию/ионизаџию метиленового голубого. Возрастание кониентрации наночастии в матрице с 3 до $10 \%$ пятикратно увеличивает интенсивность пика катиона красителя. Наблюдаемый рост ионного выхода обсуждается, исходя из явлений локального разогрева и локализированного плазмонного резонанса при облучении УФ лазером. 


\section{REFERENCES}

1. Guo Z., Ganawi A.A., Liu Q., He L. Nanomaterials in mass spectrometry ionization and prospects for biological application. Anal. Bioanal. Chem. 384 (2006) 584.

2. Chen C.-T., Chen Y.-C. Desorption/ionization mass spectrometry on nanocrystalline titania sol-gel-deposited films. Rapid Commun. Mass Spectrom. 18 (2004) 1956.

3. Нио H., Shen M., Ebstein S.M., Guthermann H. Surface-assisted laser desorption and ionization mass spectrometry using low-cost matrix-free substrates. J. Mass. Spectrom. 46 (2011) 859.

4. McLean J.A., Stumpo K.A., Russel D.H. Size-selected $(2-10 \mathrm{~nm})$ gold nanoparticles for matrix assisted laser desorption ionization of peptides. J. Am. Chem. Soc. 127 (2005) 5304.

5. Yonezawa T., Kawasaki H., Tarui A. et al. Detailed investigation on the possibility of nanoparticles of various metal elements for surface-assisted laser desorption/ionization mass spectrometry. Anal. Sci. 25 (2009) 339.

6. Chiu T.-C., Chang L.-C., Chiang C.-K., Chang H.-T. Determining estrogens using surface-assisted laser desorption/ionization mass spectrometry with silver nanoparticles as the matrix. J. Am. Soc. Mass Spectrom. 19 (2008) 1343.

7. Hua L., Chen J., Ge L., Tan S.N. Silver nanoparticles as matrix for laser desorption/ionization mass spectrometry of peptides. J. Nanopart. Res. 9 (2007) 1133.

8. Shrivas K., $W u$ H.-F. Applications of silver nanoparticles capped with different functional groups as the matrix and affinity probes in SALDI-TOF and AP-MALDI- ion trap mass spectrometry for rapid analysis of sulphur drugs and biothiols in human urine. Rapid Commun. Mass Spectrom. 22 (2008) 2863.

9. Spencer M.T., Furutani H., Oldenburg S.J. et al. Gold nanoparticles as a matrix for visiblewavelength single-particle matrix-assisted laser desorption/ionization mass spectrometry of small biomolecules. J. Phys. Chem. C. 112 (2008) 4083.

10. Awazu K., Fujimaki M., Rockstuhl C. et al. A plasmonic photocatalyst consisting of silver nanoparticles embedded in titanium dioxide. J. Am. Chem. Soc. 130 (2008) 1676.

11. Krylova G.V., Gnatyuk Yu.I., Smirnova N.P. et al. Ag nanoparticles deposited onto silica, titania and zirconia mesoporous films synthesized by sol-gel template method. J. Sol-Gel Sci. Technol. 5 (2009) 216.

12. Cai $W$., Hofmeister $H$., Rainer $T$. Surface effect on the size evolution of surface plasmon resonances of $\mathrm{Ag}$ and $\mathrm{Au}$ nanoparticles dispersed within mesoporous silica. Physica E. 11 (2001) 339.

13. Yang L., Li G.H., Zhang J.G., Zhang L.D. Fine structure of the Plasmon resonsnce absorption peak of $\mathrm{Ag}$ nanoparticles embedded in partially oxidized Si matrix. Appl. Phys. Lett. 78 (2001) 102.

14. Bi H., Cai W., Shi H., Liu X. Optical absorption of Ag oligomers dispersed within pores of mesoporous silica. Chem. Phys. Lett. 357 (2002) 249.

15. Penga S., McMahona J.M., Schatzb G.C. et al. Reversing the size-dependence of surface plasmon resonances. PNAS. 107 (2010) 14530.

16. Smithard M.A. Size effect on the optical and paramagnetic absorption of silver particles in a glass matrix. Solid State Commun. 13 (1973) 153.

17. Charlé K.P., Frank F., Schulze W. The optical-properties of silver microcrystallites in dependence on size and the influence of the matrix environment. Ber Bunsen Phys. Chem. 88 (1984) 350.

18. Govorov A.O., Richardson H.H. Generating heat with metal nanoparticles. NanoToday. 2 (2007) 30.

19. Yeshchenko O.A., Dmitruk I.M., Alexeenko A.A. et al. Size-dependent surface-plasmonenhanced photoluminescence from silver nanoparticles embedded in silica. Phys. Rev. B. 79 (2009) 235438.

20. Kucherenko M.G., Chmereva T.M., Kislov D.A. Energy transfer in molecular systems at the surface of metal solids and nanoparticles. High Energy Chem. 43 (2009) 587.

21. Kislov D.A., Rohanov A.B. Fast mode tripletsinglet nonradiative transfer of electronic excitation energy between the dye molecules in the presence of metallic nanoparticles. Inter. Conf. «Lomonosov-2011» (2011, Moscow, Russia). 31 (in Russian).

Received 27.12.2012, accepted 17.06.13 